\title{
A Review Agenda: Grading Certification And Initial Public Offerings (Ipos).
}

\author{
Seema Verma ${ }^{1}$, Dr. Satish Kumar ${ }^{2}$ \\ ${ }^{1}$ Research scholar in school of management at Gautam Buddha University Greater Noida. INDIA, \\ ${ }^{2}$ Assistant professor in school of management at Gautam Buddha University, Greater, INDIA, Noida.
}

\begin{abstract}
:
Purpose: The purpose of this paper is produce the extensive literature review regarding influence of grading on the most known phenomenon that is underpricing and as well on long run performance. Further, to explore a scope for the future empirical study in this direction.

Design/methodology/approach: This review covers an inventory of extensive literature review of empirical and conceptual studies published from 2008 to 2014 which are related to impact on - a. listing day's performance; $b$. long run performance of IPOs. The review of literature is in a chronological order 12 past studies which serve for the fourth and fifth objective of my research study.

Findings: This review provides a coherent summary of past studies and produce evidence on relationship between variables and grading. It considers the initial work and unremitted up to recent developments in identifying prospects of rating / grading certification in IPOs. The findings throws light on role, importance and scope of credit rating / grading on listing day's performance of IPOs in and post listing performance. These findings have important implications for investors to investment decisions making while choosing suitable IPO as per their interest. This phenomenon also assists to issuers who do not want to leave money on table and want to survive for a long in capital market.
\end{abstract}

Originality/value: This is my original review paper which is based on second chapter of my thesis.

Article type: Review paper

Key Words: Initial public offerings (IPO), Long run performance, Underpricing, Grading, Initial return (IR)

\section{Introduction}

Indian economy has been an example to initiate reforms time to time since industrial policy reforms in 1991. Since 1991, the process of financial sector reforms programme have been ongoing in India. With prospect of capital market, evidence been seen since abolition of Controller of Capital Issues (CCI) to replacement with establishment of Securities Exchange Board of India (SEBI) in 1988 but received the statutory power on $30^{\text {th }}$ January 1992. SEBI has the multi pronged duty to promote the healthy growth of capital market and protect the investors' interest, registration and regulation of intermediates and capital market respectively. SEBI is the apex body, which act as father for whole capital market in India. Hence, the power to introduce the reforms rest in the hand of SEBI. The reforms have been developed in safeguard of issuers and investors for the purpose of efficient and effective functioning of capital market.

Be a part of a series of reform initiatives to protect investors' interest, the market regulator Securities and Exchange Board of India (SEBI hereinafter) had introduced the concept of grading to public issues on a optional basis but later on the optional grading provision has become 'mandatory grading' to public issues in May, 2006. Which came in form of assisting the fundamental position of those companies which are not listed with the stock exchanges [viz. Initial Public Offerings (IPOs)]? IPO grading service is provided by some credit rating agencies (CRAs), including ICRA, CRISIL, Fitch Ratings India and CARE, registered with SEBI. According to SEBI, SEBI will not certify the assessment made by the grading agency. The main objective of such IPO grading is to enable investors to have an independent opinion about to make investment in an unlisted company. Though grading has been deoptional for companies from $4^{\text {th }}$ February 2014.

\subsection{IPO Grading}

In March 2007 the Securities Exchange Board of India (SEBI), the securities market regulator in India, announced grading necessary for all initial public offerings (IPO) entering the capital market to get a grading from one of the registered credit rating agencies. This provision has the objective to beat the principle of "flyby- over a -night" and to prevent the investment interests of common investors who are known as retail investors. Thus, Mandatory IPO grading was to be effective from May 1, 2007.

Presently, there are seven credit rating agencies in India, registered with SEBI: CRISIL ltd, CARE ltd, ICRA ltd, Brickwork Ratings India Pvt. Ltd, SMERA Ratings ltd, Infomerics Valuation and rating Pvt. Itd, India 
Ratings and Research Pvt. Itd (formerly Fitch). CRISIL is owned by Standard and Poor. Moody's is the largest shareholder in ICRA.

IPO grade is the rating assigned by a Credit Rating Agency (CRA) registered with SEBI, to the IPO of equity shares or any other financial security which may be converted into or exchanged with equity shares at a later date. The grade represents a relative assessment of the fundamentals strengths of the issuer company in relation to the other listed equity companies, which are already in existence in terms of trading at recognized stock exchange in India. Generally grading is assigned on a five-point point scale with a higher score to lower score which indicate the stronger fundamentals and vice versa as below.

IPO grade 1: Poor fundamentals

IPO grade 2: Below-average fundamentals

IPO grade 3: Average fundamentals

IPO grade 4: Above-average fundamentals

IPO grade 5: Strong fundamentals

IPO grading may be done either before filing the draft offer documents with SEBI or thereafter. Though, the Prospectus/Red Herring Prospectus, as the case may be, must contain the grade/s given to the IPO by all/ any CRAs approached by the issuer company for grading such IPO. Fascinatingly, IPO grades are not assessed taking into account the offer price at which the IPO is expected to be issued. As per the SEBI regulation, companies rather than investor-protection fund would bear the costs of the grading process. The cost of grading each issue is approximately Rs 500,000 and the grading process takes around 3-4 weeks.

Grading of IPOs was introduced earlier as an optional measure by SEBI as part of its initiatives aimed at protecting investors' interests. Later on it has become mandatory for the safeguard of retail investors with the purpose of decreasing the influence of "information asymmetry" phenomenon. Presently, the IPO Grading exercise is also an attempt to ensure that the retail investors have some "information" about the fundamentals of the firms going public (Khurshed; Paleari et all 2008).

Grading of an initial public offer (IPO), which had earlier been made mandatory, has now become deoptional with effect from 4th February 2014. SEBI recently came up with new guidelines upon the request of Investor Associations and Association of Investment Bankers of India (AIBI). The decision came after much debate on the grading system as it was argued that these ratings can not be a basis for investment. Ratings only talk about the fundamentals of the listing company and have nothing to do with the valuations. The grading was expected to improve the IPO pricing efficiency by providing comprehensive issue-related information to the capital market, especially to the retail investors. But there is no evidence to support IPO pricing improvement due to the introduction of IPO grading (Jacob and Agarwalla, 2012). Therefore, again IPO grading is optional which was become mandatory after May 2007 in India.

In addition, SEBI also made IPO grading mechanism "voluntary" instead of "mandatory", amending SEBI (Issue of Capital and Disclosure Requirements) Regulations, 2009. "Considering the requests received from market participants, investor associations and Association of Investment Bankers of India (AIBI), the recommendation of the advisory committee of SEBI, and to align with the principles laid down by Financial Stability Board (FSB) on reducing the reliance on Credit Rating Agencies, the Board approved the proposal to make the IPO grading mechanism "voluntary" as against the current provision of the same being "mandatory"," said SEBI. (Source - http://www.thehindu.com/business/Industry/sebi-makes-ipo-grading-mechanismvoluntary/article5498323.ece, visted on 2/12/2015 )

\subsection{Certification mechanism and IPO Performance:}

IPO literature has explored various quality signaling instruments which reflect or certify the quality of IPOs for a long time. Since the early 1970s, several studies have conducted on underwriter reputation mechanism with relation to initial listing day return (McDonald and Fisher, 1972; Block and Stanley, 1980; Neuberger and LaChapelle, 1983; Beatty and Ritter, 1986; Johnson and Miller, 1988; Carter and Manaster, 1990; Booth and Chua, 1996; Nanda and Yun, 1997; Carter, Dark and Singh, 1998). All these studies document that, on average, short-run returns are less positive for IPOs which are associated with more prestigious underwriters.

Apart from this some popular methods of certification or signaling mechanism have been auditor reputation, bank relationship, venture capitalist affiliation, analyst coverage, financial institutions affiliation and business group affiliation. These certifications have been found to have some impact on the IPO pricing efficiency. For instance, association with venture capitalists (Barry et al. 1990, Megginson and Weiss 1991) found to reduce underpricing. On the other hand some results based on these certification have not been conclusive that certification reduces the degree of information asymmetry resulting in lesser underpricing. This could be due to proxy bias as it is an indirect way of measuring the quality of an IPO. 
Indian stock market is an emerging market where certification is crucial for investors as major chunk of the retail investors are with relatively low rate of financial literacy and, at the same time, institutions may take advantage of agency problem and insider trading phenomenon.

Financial literacy has assumed greater importance in recent years especially from 2002 as financial markets have become increasingly complex and the common man finds it very difficult to make informed decisions (Ramakrishnan, 2011). Moreover, "Poor investment decisions may occur due to the limited information processing capabilities of lay investors and the 'information overload' produced by the information disclosure" (Jain and Sharma, 2008).

Marisetty and Subrahmanyam (2008) produced that underpricing is $92.7 \%$ was in India for the sample of IPOs dating from 1990 to 2007 and group affiliation, as a certification mechanism, fails to reduce the information asymmetry and, on the contrary, business group affiliated firms are more underpriced than standalone firms. During 1990 - 2000 many IPOs in India have vanished looting several millions of public funds. Hence, India is a classical case where certification is very crucial to safe guard investors' wealth.

Grading of an IPO is a latest reform in Indian capital market, introduced by SEBI (Regulator of stock market) and made it mandatory in 2010. It is to be assumed that grading reduces the degree of information asymmetry among various types of investors. It is beneficial for retail investors from the investment point of view. As Deb and Marisetty (2008), found (a) degree of underpricing is lower in post grading regime; (b) retailers subscription is higher in better graded IPOs; (c) better graded IPOs attract higher liquidity and exhibit lower risk.

\subsection{Importance of Grading}

IPO grading is a service intended to facilitate the appraisal of equity issues offered by unlisted companies to public. The grade, assigned by authorized credit rating agencies (CRAs), including ICRA, CRISIL, Fitch Ratings India and CARE, registered with SEBI to any individual issue, may produce a relative appraisal of the 'fundamentals' of that issue in relation to the universe of other listed equity securities in India. However, IPO grading may provide 'an independent assessment of fundamentals' to assist comparative assessment that would prove to be a useful investment tool for prospective investors. The methodology of such grading is to consider a five-point scale with a higher score indicating stronger fundamentals. In this perspective, this review provides an overview on IPO grading in India.

The SEBI aims at a scenario where a rating agency would rather grade the total equity of a company rather than a specific one-time issue of equity. This, SEBI feels, would help the development of the primary market tremendously. (SOURCE- http://articles.economictimes.indiatimes.com/2007-03-23/news/ visited on 212-2015)

IPO grading covers both internal and external aspects of a company seeking to make an IPO in general. The internal factors include competence and effectiveness of the management, profile of promoters, marketing strategies, size and growth of revenues, competitive edge, technology, operating efficiency, liquidity and financial flexibility, asset quality, accounting quality, profitability and hedging of risks. Among external factors, the key one is the industry and economic/business environment for the issuer. Grading is due diligence process. Here, it is important to note that internationally, the global rating agencies such as Standard \& Poors and Moodys do not perform grading of IPOs at all. While Standard \& Poors is the majority stakeholder in CRISIL Ltd, Moodys is the single biggest stakeholder in ICRA Ltd (Saha, 2006, pg. no. 117). There are various positive sides of an IPO grading. The most significant factors that go in favour of IPO grading are: (a) Professional and independent appraisal, (b) Removal of information overload, (c) impediment for weak companies, (d) improving investors' sophistication. Theses positive sides strengths the importance of grading system for financial investment instruments.

\subsection{SEBI Guidelines Regarding IPO Grading}

In exercise of the powers conferred under sub-section (1) of Section 11 of the Securities and Exchange Board of India Act, 1992, it had been decided to amend the SEBI (DIP) Guidelines, 2000. The amendment regarding IPO grading had been made on 24th April, 2006 (vide SEBI Circular No. SEBI/CFD/DIL/DIP/21/2006/24/4 dated April 24, 2006) and came into force with immediate effect. SEBI has also circulated the following amendments of IPO grading to all merchant bankers (who perform as lead managers/ intermediary in management of capital issues of primary capital market in India) as well as stock exchanges. These amendments are summed up as below:

\section{(1) Pre-Issue obligations in case of IPO grading:}

An unlisted company making an IPO of equity shares or any other security, which may be converted into or exchanged with equity shares at a later date may opt to obtain grading for such an IPO from one or more credit rating agencies. Where an issuer opts to obtain IPO grading, it shall disclose all grades so obtained by it, including unaccepted grades, in the prospectus and abridged prospectus. 


\section{(2) Grading description in Contents of the prospectus:}

If IPO grading has been obtained by issuer. The disclosure of all grades so obtained, including unaccepted grades and reference of the page number where details of IPO grading, as mentioned are - (i) Name of the credit rating agency from which grading has been obtained for the proposed IPO of equity shares or any other security which may be converted into or exchanged with equity shares at a later date and the grading so obtained, including unaccepted grades. (ii) If grading has been obtained from more than one credit rating agency, disclosure shall be made of all the grades so obtained, including unaccepted grades. (iii) The rationale/description of the grading so obtained, as furnished by the credit rating agencies

\section{Review Of Literature}

Here the review of literature in a chronological order in a tabular form, which provides a clear understanding about related issues with grading mechanism at a first sight. All these studies are conducted in India as only India is the first country to introduce the concept of grading / credit rating in IPOs. The following table accomplishes the review of literature of past published empirical studies.

Table 1: Produce summary of past published studies on Grading certification.

\begin{tabular}{|c|c|c|c|c|c|}
\hline $\begin{array}{l}\text { S. } \\
\text { No }\end{array}$ & $\begin{array}{l}\text { Authors/ } \\
\text { yr }\end{array}$ & $\begin{array}{l}\text { Sample size, time } \\
\text { frame, Region, } \\
\text { Methodology and } \\
\text { Techniques Used }\end{array}$ & $\begin{array}{l}\text { Measurement } \\
\text { / evaluation }\end{array}$ & $\begin{array}{l}\text { Variables: } \\
\text { Dependent and } \\
\text { Independent }\end{array}$ & Findings of the study \\
\hline 1 & $\begin{array}{l}\text { Jain and } \\
\text { Sharma } \\
(2008)\end{array}$ & $\begin{array}{lr}\text { India, } & \text { Qualitative } \\
\text { approach- } & \text { Through } \\
\text { observations and views } \\
\text { from news literature. }\end{array}$ & $\begin{array}{l}\text { Implied } \\
\text { observation is } \\
\text { used to } \\
\text { recommend on } \\
\text { grading } \\
\text { mechanism. }\end{array}$ & $\begin{array}{lr}\text { Grading } & \\
\text { mechanism- } & \text { its } \\
\text { features, } & \text { role, } \\
\text { reflection } & \text { on } \\
\text { investors, } & \\
\text { information } & \\
\text { overload. } & \end{array}$ & $\begin{array}{l}\text { Grading ensures meaningful information } \\
\text { to the investors and facilitating informed } \\
\text { decision-making. Small firms face } \\
\text { difficulty to raise fund by IPO, so } \\
\text { grading would enhance the confidence of } \\
\text { them. Grading is a progressive and } \\
\text { innovative regulation, it would restrict } \\
\text { unviable fund. It would also reduce the } \\
\text { information asymmetry problem and } \\
\text { push the confidence of retail investors. It } \\
\text { would counteract on information } \\
\text { overload as it is in safeguard of } \\
\text { investors. }\end{array}$ \\
\hline 2 & $\begin{array}{l}\text { Deb and } \\
\text { Marisetty } \\
(2008)\end{array}$ & $\begin{array}{l}159 \text { IPOs }(\mathrm{FP}+\mathrm{BB}) \\
\text { for the period April } \\
2006-\text { August-2008, } \\
\text { Data source- PDS \& } \\
\text { Prowess, India, Event } \\
\text { study and quantitative } \\
\text { Cross section multiple } \\
\text { regression, Descriptive } \\
\text { statistics and T- test }\end{array}$ & $\begin{array}{l}\text { Natural } \\
\text { logarithm used } \\
\text { in issue size, } \\
\text { dummy } \\
\text { variable- } \\
\text { grading, } \\
\text { significance } \\
\text { level- 10\% for } \\
\text { return and 5\% } \\
\text { for factors. }\end{array}$ & $\begin{array}{l}\text { Underpricing, } \\
\text { short run return- } 2 \\
\text { days to } 7 \text { days and } \\
90 \text { days of listing, } \\
\text { subscription, } \\
\text { liquidity and risk; } \\
\text { Issue size, grading, } \\
\text { group affiliation, } \\
\text { total assets, return } \\
\text { on networth, debt } \\
\text { to equity ratio }\end{array}$ & $\begin{array}{l}\text { Average initial return was } 21.3 \% \text { in a } \\
\text { sample, UP is low in graded IPOs than } \\
\text { non graded IPOs, QIBs subscription is } \\
\text { low in graded IPOs ( } 19.046 \text { times than } \\
\text { (34.5) times in non graded IPOs, total } \\
\text { subscription is higher in better graded } \\
\text { IPOs. Grading does not impact risk, } \\
\text { Graded IPOs show higher average } \\
\text { turnover ratio than non graded IPOs, } \\
\text { Issue size is the predictor of } \\
\text { underpricing because larger the issue } \\
\text { size lesser the underpricing. }\end{array}$ \\
\hline 3 & $\begin{array}{l}\text { Poudyal } \\
(2008)\end{array}$ & $\begin{array}{l}63 \text { IPOs from April } \\
2005 \text { to November } \\
2008 \text {. Data source- } \\
\text { Prowess, Capital line, } \\
\text { INSIGHT } \\
\text { (insight.asiancerc.com) } \\
\text { India, Event study } \\
\text { and Quantitative } \\
\text { Regression model, T- } \\
\text { statistics, F- statistics, } \\
\text { R-square. }\end{array}$ & $\begin{array}{l}\text { Log } \\
\text { transformed } \\
\text { for variables- } \\
\text { Regression } \\
\text { model is at } 1 \% \\
\text { significance } \\
\text { level and } \\
\text { explanatory } \\
\text { power at } 10 \% \\
\text { level of } \\
\text { significance. }\end{array}$ & $\begin{array}{l}\text { Underpricing or } \\
\text { Initial listing day } \\
\text { return; IPO Grades. } \\
\text { Liquidity } \\
\text { turnover ratio; } \\
\text { (issue size, age, } \\
\text { subscription rate, } \\
\text { post returns, } \\
\text { method of issuing- } \\
\text { fixed price and } \\
\text { book built, non } \\
\text { promoter holding } \\
\text { as independent } \\
\text { variable) } \\
\text { Price to book ratio } \\
\text { (Ratio of listed } \\
\text { share price to book } \\
\text { value of share } \\
\text { reported in the } \\
\text { company balance } \\
\text { sheet) }\end{array}$ & $\begin{array}{l}\text { Higher IPO grades lead to lower } \\
\text { underpricing, improvement in } \\
\text { subscription rate across all class of } \\
\text { investors. IPO grades inversely related to } \\
\text { listing day turnover ratio indicating that } \\
\text { higher IPO grades don't exhibit high } \\
\text { turnover ratio. Book built IPOs generate } \\
\text { more liquidity in the market than fixed } \\
\text { price IPOs and they also perform better } \\
\text { in long run. Issue size, age, non } \\
\text { promoter holding show negative relation } \\
\text { with short term liquidity. Underpricing } \\
\text { leads to high over subscription. Higher } \\
\text { the IPO grades better the subscription } \\
\text { rate, and predict the attraction of } \\
\text { retailers' investment. IPO grades do not } \\
\text { explain long term performance of IPOs. }\end{array}$ \\
\hline 4 & $\begin{array}{l}\text { Khurshed,P } \\
\text { aleari, } \\
\text { Pande and }\end{array}$ & $\begin{array}{l}251 \text { IPOs in which } 47 \\
\text { graded IPOs for the } \\
\text { period } 1999-2008,\end{array}$ & $\begin{array}{l}\text { Proxy for } \\
\text { Reputation of } \\
\text { investment }\end{array}$ & $\begin{array}{l}\text { Grading; Issue size, } \\
\text { age, subscription } \\
\text { pattern- } \quad \text { (QIBs, }\end{array}$ & $\begin{array}{l}\text { Grading does not influence the } \\
\text { underpricing of book built IPOs. } \\
\text { Reputation of investment banker has not }\end{array}$ \\
\hline
\end{tabular}




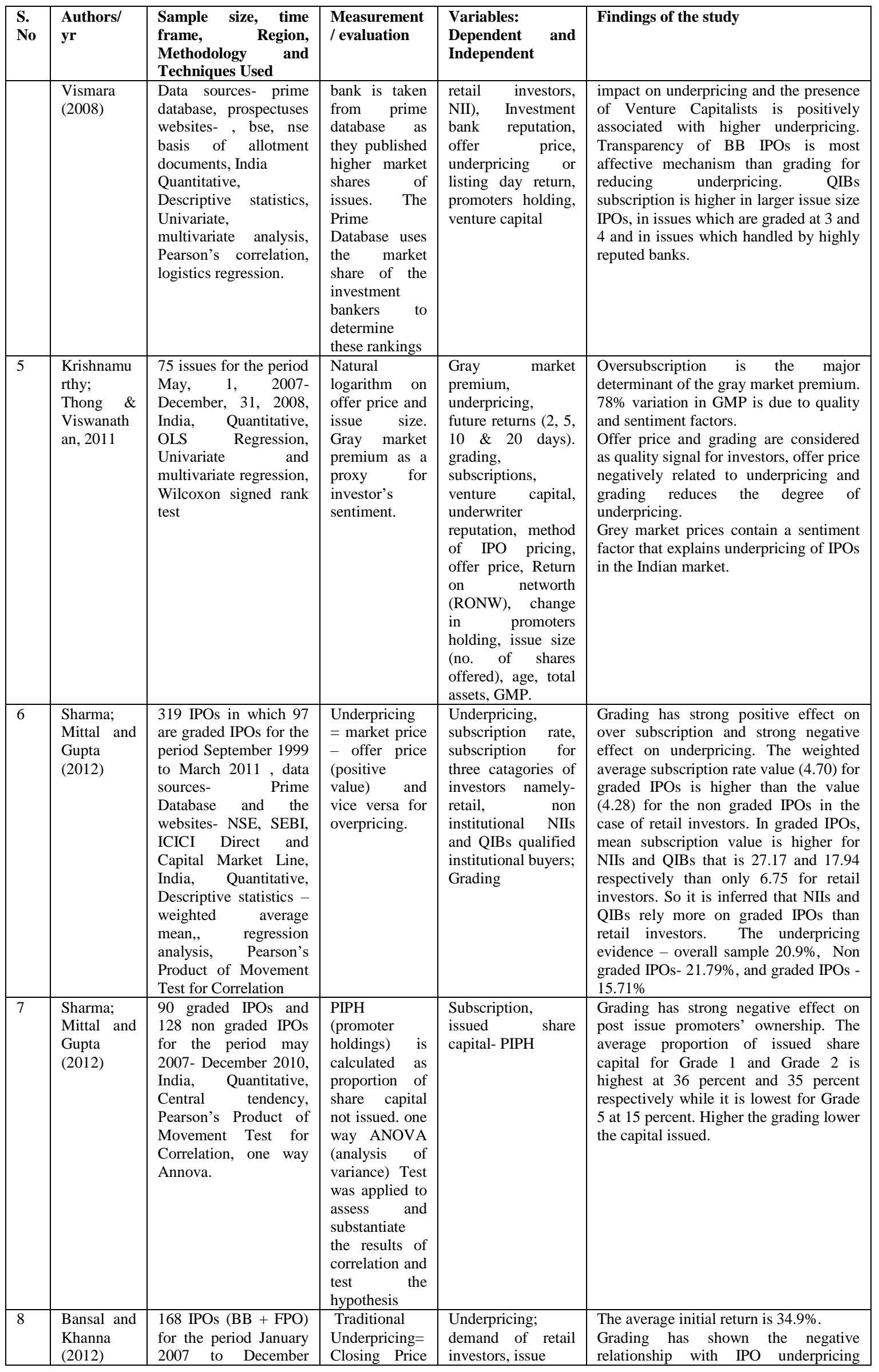




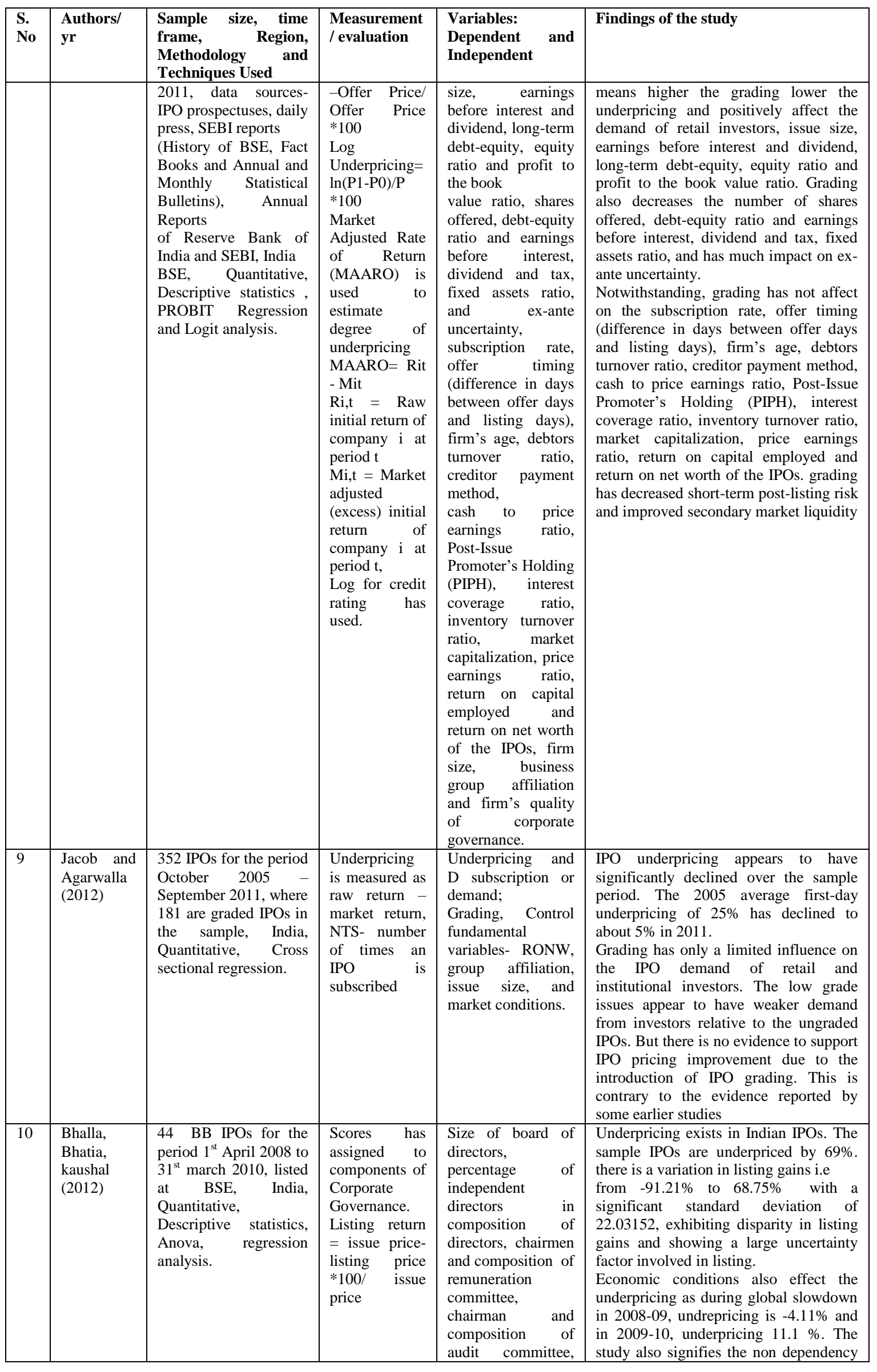


A Review Agenda: Grading Certification And Initial Public Offerings (Ipos).

\begin{tabular}{|c|c|c|c|c|c|}
\hline $\begin{array}{l}\text { S. } \\
\text { No }\end{array}$ & $\begin{array}{l}\text { Authors/ } \\
\text { yr }\end{array}$ & $\begin{array}{lr}\text { Sample size, time } \\
\text { frame, Region, } \\
\text { Methodology and } \\
\text { Techniques Used }\end{array}$ & $\begin{array}{l}\text { Measurement } \\
\text { / evaluation }\end{array}$ & $\begin{array}{l}\text { Variables: } \\
\text { Dependent and } \\
\text { Independent }\end{array}$ & Findings of the study \\
\hline & & & & $\begin{array}{lr}\text { Chairman } & \text { of } \\
\text { Investor's } & \\
\text { Grievances } & \\
\text { Committee, } & \\
\text { Composition } & \text { of } \\
\text { Investor's } & \\
\text { Grievances } & \\
\text { Committee, } & \text { IPO } \\
\text { Grading, } & \text { Risk } \\
\text { Management } & \\
\text { Policy. } & \\
\end{array}$ & $\begin{array}{l}\text { of Underpricing of IPOs in Indian } \\
\text { Capital Market on the Corporate } \\
\text { Governance mechanism of the } \\
\text { companies. This also indicates that even } \\
\text { in many of the developed countries the } \\
\text { corporate governance reforms and } \\
\text { practices have a positive impact on } \\
\text { underpricing of IPO but in India it still } \\
\text { requires a long way to find such } \\
\text { relationship. }\end{array}$ \\
\hline 11 & $\begin{array}{l}\text { Mittal, } \\
\text { Gupta, } \\
\text { Sharma } \\
(2013)\end{array}$ & $\begin{array}{l}218 \text { IPOs in which } 90 \\
\text { graded IPOs for the } \\
\text { period May 2007- } \\
\text { December 2010, data } \\
\text { source- NSE, ICICI } \\
\text { Direct website and } \\
\text { Prime Database, India, } \\
\text { Quantitative, } \\
\text { Pearson's Product of } \\
\text { Movement Test and } \\
\text { central tendency } \\
\text { measures, one way } \\
\text { Anova - p value, T } \\
\text { stats }\end{array}$ & $\begin{array}{ll}\text { Very } & \text { short } \\
\text { run- up to I } \\
\text { month, short } \\
\text { run- up to } 6 \\
\text { months, } \\
\begin{array}{l}\text { Long } \\
\text { period- } \\
\text { beyond } \\
\text { months }\end{array}\end{array}$ & $\begin{array}{l}\text { Underpricing, } \\
\text { oversubscription, } \\
\text { returns - market } \\
\text { appreciation, } \\
\text { subscription } \\
\text { involves retailers, } \\
\text { NIIs and QIBs; } \\
\text { Grading or grades- } \\
1,2,3,4,5\end{array}$ & $\begin{array}{l}\text { IPO grading has strong positive effect on } \\
\text { demand/oversubscription. A weak } \\
\text { impact on returns, little or nil impact on } \\
\text { underpricing and strong negative effect } \\
\text { on proportion of issued share capital. } \\
\text { Demand (subscription) increases as } \\
\text { grades increase. } \\
\text { Oversubscription at overall level for } \\
\text { Grade } 5 \text { is highest at } 35.68 \text { times } \\
\text { compared with lowest of } 2.78 \text { times for } \\
\text { Grade } 1 \text {. Study rejects this argument that } \\
\text { Better the graded better the return hence } \\
\text { direct relationship between grades and } \\
\text { returns for short run. }\end{array}$ \\
\hline 12 & $\begin{array}{l}\text { Sharma; } \\
\text { Mittal and } \\
\text { Gupta } \\
(2014)\end{array}$ & $\begin{array}{l}319 \text { IPOs in which } 222 \\
\text { are non graded and } 97 \\
\text { are graded IPOs, India, } \\
\text { Data source- Prime } \\
\text { database, NSE, SEBI, } \\
\text { Capital line } \\
\text { Empirical } \\
\text { Quantitative } \\
\text { Pearson coefficient } \\
\text { correlation, weighted } \\
\text { mean, }\end{array}$ & $\begin{array}{l}\text { Underpricing } \\
\text { is calculated as } \\
\text { closing price } \\
\text { on listing day- } \\
\text { issue price / } \\
\text { issue price. }\end{array}$ & $\begin{array}{l}\text { Underpricing ; } \\
\text { Grades- } 1,2,3,4, \\
\text { and } 5 \text {, The outcome } \\
\text { values of this test } \\
\text { lie between } 1 \text { and - } \\
1 \text { with } 0 \text { being } \\
\text { neutral. Negative } \\
\text { value of correlation } \\
\text { signals 'inverse' } \\
\text { relationship while } \\
\text { positive value } \\
\text { signals 'direct' or } \\
\text { parallel } \\
\text { relationship. }\end{array}$ & $\begin{array}{l}\text { IPO grading has strongly negative effect } \\
\text { on underpricing so grading is inversely } \\
\text { related to listing day's return. The } \\
\text { overall mean UP is } 20.09 \% \text {. The mean } \\
\text { UP for graded IPOs is } 15.71 \% \text { that is } \\
\text { less than } 21.79 \% \text { for non graded IPOs } \\
\text { While weighted mean produce reverse } \\
\text { picture as weighted average UP is } \\
10.93 \% \text { for graded IPOs and } 6.63 \% \text { for } \\
\text { Non Graded IPOs. }\end{array}$ \\
\hline
\end{tabular}

The table 2 describes the identified variables which are related to grading mechanism directly and indirectly and clearly exhibits relationship of dominant variables to grading.

Table 2: Depicts relationship of various variables with grading

\begin{tabular}{|l|l|l|l|}
\hline S. No. & Variable/s & Relationship / Impact & Studies \\
\hline 1 & Overall subscription rate & Positive (higher) & $\begin{array}{l}\text { Deb and Marisetty (2008); Poudyal (2008); Sharma; } \\
\text { Mittal and Gupta (2012); Mittal, Gupta, Sharma } \\
(2013)\end{array}$ \\
\cline { 3 - 4 } & & No & Bansal and Khanna (2012) \\
\cline { 3 - 4 } & & Positive (higher) & Khurshed; Paleari; Pande and Vismara (2008) \\
\cline { 3 - 4 } & Liquidity / Turnover Ratio & No & Poudyal (2008) \\
\hline 5 & Long term performance & Negative & Poudyal (2008) \\
\hline 5 & Post issue promoter holding & Negative & $\begin{array}{l}\text { Deb and Mittal and Gupta (2012 } \\
\text { Mittal and Gupta (2012); Bansal and Khanna (2012); }\end{array}$ \\
\cline { 3 - 4 } & Listing day's return & Weak impact & Mittal, Gupta, Sharma (2013) \\
\hline 7 & Demand (investors' subscription) & Limited influence & Jacob and Agarwalla (2012) \\
\hline & $\begin{array}{l}\text { Demand of retail investors, Issue } \\
\text { size, Earnings Before Interest and } \\
\text { Dividend, long-term debt-equity, } \\
\text { Equity ratio and profit to the book } \\
\text { value ratio. }\end{array}$ & Positive & Bansal and Khanna (2012) \\
\hline
\end{tabular}

\section{Source: complied from various past studies}




\section{Findings And Conclusion:}

(The findings are grouped as per the objective of this paper)

The grading certification has come as a safeguard weapon for retail investors. As it was became mandatory by SEBI with the intention of reducing degree of underpricing in IPOs. Several empirical studies have been tested to measure implication of this intention. IPO underpricing appears to have significantly declined over the sample period. The 2005 average first-day underpricing of $25 \%$ has declined to about $5 \%$ in 2011 (Jacob and Agarwalla, 2012). Grading reduces the degree of underpricing (Krishnamurthy; Thong \& Viswanathan, 2011). In a same line, the findings of flowing studies: (Poudyal, 2008); (Deb and Marisetty, 2008) ;(Sharma; Mittal and Gupta, 2012); (Bansal and Khanna, 2012); (Mittal; Gupta and Sharma, 2013); Sharma; Mittal and Gupta, 2014) support the hypothesis that higher the grading lower the underpricing in IPOs on listing day. Whereas Khurshed; Paleari; Pande and Vismara (2008) advocates that grading does not influence the underpricing in Book built IPOs. Even the transparency of Book built IPOs is most affective mechanism for reducing the degree of underpricing.

Moreover, the relationship of grading certification has been measured with one of the most significant variable namely demand of investors or subscription rate of investors. It is to be assumed that the grading produces signals of good quality of Issuer to investors. Where the retail investors (Non informed) do more rely on highly graded IPOs and go for higher subscription in highly graded IPOs. Higher grading attracts high demand from retail investors (Poudyal, 2008 and Bansal and Khanna, 2012). On the contrary, Grading has only a limited influence on the IPO demand of retail and institutional investors (Jacob and Agarwalla, 2012). Apart from this IPO grade's ability in predicting the short term liquidity of the IPO shows negative relation with turnover ratio (Poudyal, 2008). Which means higher grading can not have the explanatory power to liquidly. Moreover the relationship of grading mechanism with overall subscription rate is also under controversy as empirical evidence given by Poudyal, 2008; Deb and Marisetty, 2008; Sharma; Mittal and Gupta, 2012 advocate that overall subscription rate is high in better graded IPOs. Whereas Bansal and Khanna, 2012 produce reciprocate evidence which advocate that grading does not have impact on overall subscription rate.

Interestingly the empirical evidences are controversial. Here is table $\mathbf{2}$ in which sought variables have been extracted on which a academic research could be explored by following a directional domain. The review clearly describes the role of grading certification specially in listing day's performance. (Refer table 1)

Here on the basis of tested hypotheses the saying of - "the proposed grading system would no doubt serve as an additional input towards assisting the average Indian investor in making the right investment choices" (Jain and Sharma, 2008). Further, the grading mechanism could be tested with other variables related to IPOs and also with long run performance of IPOs. Therefore comparative study via underpricing: pre grading regime and post grading regime could be explored further in Indian capital market. Along with credibility of financial information with grade level could be tested which would introduce a new model to examine reliability of credit rating agencies who are supposed to assign grade as per past financial performance of issuer company. So the credibility of due diligence process of rating agencies could be explored in near future study. This new domain may produce helping hand to investors so that they can adopt grading as a quality signal instrument while investing for long time in particular issue.

\section{Bibliography}

[1] Bansal, R., \& Khanna, A. (2012). Do High Credit Rating IPOs Influence the Determinants of Underpricing?-A Logit Analysis. The IUP Journal of Financial Risk Management, 9(4), 7-26.

[2] Banerjee, S., \& Rangamani, K. T. (2014). IPO Grading: Selection and Under Pricing?. SCMS Journal of Indian Management, 11(1), 96-108.

[3] Barry, C. B., Muscarella, C. J., Peavy, J. W., and Vetsuypens, M. R. (1990). The role of venture capital in the creation of public companies: Evidence from the going-public process. Journal of Financial economics, 27(2), 447- 471.

[4] Bhalla, L., Bhatia, A., \& Kaushal, V. (2012). Corporate Governance and IPO Underpricing. Journal of Commerce and Accounting Research, 1(3), 35.

[5] Deb, S. S., \& Marisetty, V. B. (2010). Information content of IPO grading. Journal of banking \& Finance, 34(9), 2294-2305.

[6] IPO Grading is Mandatory, THE ECONOMIC TIMES, Mar. 23, 2007, available at http://economictimes.indiatimes.com/Markets/Stocks/IPOs/IPO_gradings_mandatory/articleshow /1795722.cms (last visited 2-122015).

[7] Jacob, J., \& Agarwalla, S. K. (2012). Mandatory IPO Grading: Does It Help Pricing Efficiency?. Available at SSRN 2195037.

[8] Jain, T., \& Sharma, R. (2008). Mandatory IPO grading: Reflections from the Indian capital markets. ICFAI Journal of Corporate and Securities Law, 5(4), 8-22.

[9] Khurshed, A., Paleari, S., Pande, A., \& Vismara, S. (2008). IPO Grading in India: Does it add value to the book building process. Unpublished Working Paper accessed from www. unibg. it/dati/bacheca/530/36104. pdf.

[10] Krishnamurti, C., Thong, T. Y., \& Ramanna, V. (2011, August). Grey market for Indian IPOs: investor sentiment and after-market performance. In 2012 Financial Markets \& Corporate Governance Conference.

[11] Mittal, S., Gupta, N. K., \& Sharma, S. K. (2012). Investor Preference and Promoter's Ownership Pattern in Graded IPOs of India. Indian Journal of Finance, 6(12), 18-25.

[12] Mittal, S., Gupta, N. K., \& Sharma, S. K. (2013). Post Issue Performance of Graded IPOs in India. Prajnan: Journal of Social and Management Sciences, Vil. XLI, (2), 2012-13. 
[13] Poudyal, S. (2008). Grading Initial Public Offerings (IPOs) in India's Capital Markets, a Globally Unique Concept. Indian Institute of Management.

[14] Ramakrishnan, Dr. (2011) Financial Literacy - The Demand Side of Financial Inclusion http://ssrn.com/abstract=1958417 or http://dx.doi.org/10.2139/ssrn.1958417

[15] Saha, S. S. (2006), SEBI's Initiative to Safeguard Investors' interest through IPO Grading, The Chartered Accountant, July 2006, pp 116-122.

[16] Sharma, S. K., Mittal, S., \& Gupta, N. K. (2012). Does Grading of IPOs Improve Demand and Underpricing? Available at SSRN 2296717.

[17] Sharma, S. K., Mittal, S., \& Gupta, N. K. (2013, February). Underpricing in Graded IPOs. In International Doctoral Convention (ISBN: 978-81-910118-6-9)(pp. 497-505). 